\title{
Sense of Selfhood in Zora Neal Hurston's Their Eyes Were Watching God
}

\author{
Lekha Nath Dhakal, Ph.D. \\ Associate Professor, Nepal Commerce Campus, T.U.
}

\begin{abstract}
Sense of selfhood constitutes one of the main ideas of Zora Neale Hurstson's novels. The central argument in this paper is the quest for identity in Hurstson's Their Eyes Were Watching God. In the novel the characters identify themselves on the basis of their inner desires and thoughts. This paperexplores that identity and selfhood changes according to human situation, realities and experiences. Human being turns into an integrated and self-aware individual through a psychological process. This article also attempts to presentthe Psychological impact of colonialism on the colonized people. It focuses on the oppressionof the whites on the black people and improper European rationalism and their disregard of the experiences of 'the other'. The novelshows that people's attempts and sense of selfhood or identity gains a great success in achieving their goals in the long run.
\end{abstract}

Key words: Selfhood, Identity, Rationalism, Black, Quest

Zora Neale Hurston considers Their Eyes Were Watching God as a deliberate and political act as well as white-black crisis. Here identity or selfhood means a person who sees himself and those who sees themselves. It is connected to watching and seeing. Post colonialism as an academic approach to literary criticism moves around this concept that the identity of black people has been oppressed throughout the history of the African Americans. Postcolonial discourse focuses on the recognition of African Americans as normal human beings as identified and possessing self or identity. Frantz Fanon, in his Black Skin, White Masks says that the sense of selfhood "is only the problematic process of access to an image of totality" (2008: xxix). This novel also captures the interests of wide range of feminist critics as it is full of female self-awareness. Another aspect of the novel is political understanding of the concept of blackness and femaleness as well. Throughout the novel Their Eyes Were Watching God, Janie, the protagonist is searching for her own self and identity. Her sense of selfhood experiences a lot of fluctuations and transformations.

The knowledge about selfhood or the self- realization has become one of the most complicated and ever growing issues in literary studies today. It has become a fascination for the critics, novelist, and the scholars alike. The terms like man, woman, body, self, individual, subject, human and so on have been repeatedly used in literary and critical studies to mention to the self of certain individual, specific community or the institution.

The idea of self hood or the identity dates back to long ago in the fourth century BC. In seventeenth century, the French philosopher Rene Descartes stated that "I think, therefore I am" (25). This changed the discussion and meanings of selfhood and identity. The history of individual has become the major source of meaning as well as the criterion to assess and evaluate life and living. "....... the thinking self was the base of what mankind could achievein their life" (Rivkin and Rayne 390). In the words of Etienne Balibar: The core of the representation of mam as the foundation of his own thoughts, actions and history has, 
for three centuries at least, not been simply a valorization of human individuality and the human species as the bearer of the universal, it has been the representation of Man as the subject. The essence of humanity of being a human, which should be present both in universality of the species and in the singularity of the individual, both as a reality and as a norm of possibility, is subjectivity. (Balibar 4)

Hans Berten's understanding of self and identity reveals that "for about three centuries modern European philosophy became involved with the question of self and subjectivity. Humanity became a major topic for literary and philosophical fantasies which examined man as self-sufficient, independent, and knowable entity". The demise of monarchy in the mid- nineteenth century intensified the rise of capitalism in Europe. Its primary slogan was as "you are what you own" (Tyson 47). It shows that major focus of capitalism was on selfhood, identity, or on individuality. Before Freud's critical study on human psyche, human mind was chiefly defined as a place where the rational and thinking "Cogito" (Brelser 145) existed.

Grania is one of the representatives of revolutionary play of Augusta Gregory, which. focuses on female individual desire rather than her submissive role. In the play when her father forced her to marry with the foreign King, she rejects the proposal and says, "My father was for King of Foreign, but I said I would take my own road" (38). In the mid-twentieth century, feminism challenged male domination and patriarchal thought of identity. It created the recognition of female self. The main argument of the feminism is that woman identity has been made silence by patriarchal society. Simone the Beauvoir writes in The Second Sex, "one is not born, but rather becomes a woman" (The Literary Theory and Criticism 319).

In Hurston's Their Eyes Were Watching God the characters like Joe, Nanny and Janie have a strong sense of selfhood or the self- realization. Nanny always talks about her own past how improperly the whites treated her daughter and even herself. It shows her inner connection with black individuality. Nanny's technique for raising awareness about black identity is to tell her own story to her granddaughter. This oral tradition to recount one's life story is one of the main techniques of telling stories of their suffering in the postcolonial literature. Nanny tells her story to Janie to influence and galvanize her fight against white people. She says:

You know honey, us colored folks is branches without roots and makes things come round in queer ways. Ah was born back due in slavery so it wasn't for me to fulfill my dreams. You can't beat nobody down so low till you rob 'em of they will. Ah didn't want to be used for a work - ox and brood - saw. Ah wanted to preach great a sermon about colored people sittin' on high but wasn't no pulpit for me. Freedom found me wid a baby daughter in mah arms. Ah knowed here you was in due world. (30)

Nanny's talking with Janie shows that she is totally pre-occupied with black woman as she knows the real situation of the black people in the society who were dominated by the Whites. Freedom is so precious. Nanny imagines herself to be a powerful leader of the black community and keeps on preaching to the black slaves and other marginalized people about the joy of freedom and independence. She gives importance to the free person who is under his control. Nanny's story emphasizes a free individual and selfconstruction. In her talking, she always recounts and expresses her anger on the Whites' wrong doings and improper behavior done to the Blacks.

Another character Janie also represents powerful sense of selfhood and self -identity. From her early childhood, she tries to show her blackness than to hide it. Her famous statements to reveal her self- identity are when she says "where is me? Ah don't she me" and her "Aw, Aw, Ah, m colored" (26). The statement presents the total picture of Janie's character. Her words for example "me", "Ah" and "colored" gives her true identity as a black girl or as a black female. This sense of identifying with her true self and announcing it in a clear way lasts as the narrative attentions on Janie's understanding.

Another important character to share the similar inclinations with Nanny and Janie is Joe Starks. His main principle for life is to build a city only for colored people. This desire discloses that Joe is passionately working to make black community aware of their own self. "Ah'mbuyin' in here and buyin' in big (40). For Starks, to enjoy freedom and to be free from Whites creates the only practical and sustainable remedy for black people. It shows that these three characters Nanny, Janie and Joe Starks represent freedom, self- 
construction, sense of selfhood, black identity and self-realization.

Janie puts emphasis on the word 'see' and links it to the word 'understanding'. She thinks that there is no understanding without seeing the things first. She repeatedly uses the word 'tell' and exposes its inadequacy if it is not matched with the word 'see'. This feature of her character depicts the unbroken part of her identity. Hurston, the narrator, draws the readers' attention towards Janie and how she was not conscious of her blackness before she was six:

.....Ah didn't know Ah wuzn't white till Ah was round six years old. Wouldn't found it out then, but a man come long takin pictures and without askin' anybody........round a weak later de man brought de pictures for Mis' Washburn to see and pay him which she did. So when we looked at the picture and everybody got pointed out there wasn't nobody left except a real dark girl with long hair standing by Eleanor.( 26)

Before this incident happened Janie considered herself a normal child among other white children. She would unconsciously define her identity by the sameness with them. This visual image reminds her of her real being or of her skin color which divides her from white children. She knows that she is a black girl. She comes to know herself through watching and 'seeing' her black color of her skin. This is the initial phase of self-identity for Janie which is nonstop black recognition in essence. From early childhood Janie is conscious about her own self and identity as her experience looking at picture shows that she is looking for her image or picture and trying to find herself to see what she looks likeJanie's restlessness is seen the short sentence "where is me?" (26). This proves how much she is eager to find herself.

Fanon argues that "identity is a socio-economical phenomenon rather than being an internal one(Black Skin, White Masks 50). After this incident Janie accepts her identity as a black girl. She is different from other white girls in her environs. Janie's self-awareness as a black girl rises and sees her blackness more than ever: 'Us lived' derehavin' fun till de chillun at school got to teasin' me 'bout livin' in de white folks' backyard" (26). When she is growing Janie experiences internal transformations within herself. In West Florida in Spring Janie spend most of the day under a blossoming pear tree in the backyard. The narrator says "it had called her to come and gaze on a mystery. From the leaf buds to snowy virginity to bloom, it stirs her tremendously. How? Why? What? Why? The rose of the world was breathing out smell. It connected itself with other vaguely felt matters that had struck her outside observation and buried themselves in her flesh" (27). This shows how Janie undergoes inner changes and the way she is supposed to see the world around her. Till now also she is unable to communicate what she is actually looking for. An unknown force has called upon her to "gaze"at a "mystery" (27).

Janie is no longer sightless and sees things brightly. The phrases like "visiting bees", "tree soaking", and "bursting buds" (27) show that she is turning into new person. Her desire to love and be loved, to see and be seen project itself through theses visual images. The rise of new consciousness in her is seen in her attachment with Jonny Taylor. The narrator states, "that was the end of her childhood" (27). Now her identity or her real self is quite confusing as she does not know what she truly desires. This confusing state of mind continues to exist till she becomes acquainted with Joe Starks. His marriage proposal and their subsequent marriage together put Janie in another chapter of her search for her identity. Life keeps on changing. Change is the rule of life. The change results in an attempt to know the real meaning of life. In both marriages Janie's ability to hurt her husbands is equal to their ability to hurt her. As her marriage to Jody worsens, she begins to detect herself: "She sat and watched the shadow of herself going about tending store and prostrating itself before Jody, while all the time she herself sat under a shady tree with the wind blowing through her hair and her clothes" (69). Soon after Jody's death she stand in front of the looking glass where she told herself to wait for her. She discovers that a handsome woman has taken her place. She tears off the kerchief Jody has given her to wear and lets down her hair. "The weight, the length, glory was there. She took careful stock of herself, then combed her hair and tied it back up again" (76). One can perceive Janie's thoughtful attempt to fashion and praise black female self and a sense of love of the black woman. More importantly, Janie has learnt to look at herself and see herself. It means that to see is to love, 
to praise, to know one's self and even others. Janie has the power to see, to enjoy and to understand the life well. In the words of Mary Helen Washington:

In her first moment of independence, Janie is not seen as autonomous subject but again as visual object, "seeing herself, seeing herself," draping before herself that "hidden mystery", that attracts men and makes her superior to women. Note that when she turns to mirror, it is not to experience her own sensual pleasure in her hair. She does not tell us how her hair felt her- did it tingle at the roots? Did she shiver with delight? - no she takes stock of herself, makes an assessment of herself. What's in the mirror that she cannot experience without it: that other that the mirror represents, looking on in judgement, recording, not her own sensations but the way other see her. In long paragraph she tells us how she has changed in the six month after Jody's death, we are told that Janie talked and laughed in the store at times and was happy except for the store. (14).

This is the finding of Janie's split selves. She has inside and outside selves. She represents her internal life as divided between two men. Her outside self exists for Joe and her inside self "she is saving up for some man she had never seen" (66). She obtains a new understanding and knowledge of her own identity as a woman and also she rises the nature of love and human relationship in a new light. Janie in her two marriages did not act as the agent of her internal desires. But rather she was half active in deciding to marry Killicks and Joe Starks. Just opposite of it, her third and final marriage to Tea Cake specified her full consciousness and presence in the course of decision making and the sense of her own agency to accept Tea Cake's proposal. Now Janie has been changed a lot and has become a new person who can decide her own life, identity and fate. This is very important for her as it signifies a moment when she is freed from patriarchal dictation of its guidelines and principles.

In the words of Harold Bloom "Power in Hurston is always potential, the demand for life, for more life. ... is the implicit basis of Hurston true religion which reminds us that only that day dawns to which we are alive" (5). The force of her own understanding of true self make Janie kill Tea Cake in self-defense ending necessarily life and love in the name of the possibility of new life again. This novel establishes Janie's character as great female of Hurston. The result is highly critical to those male defined rules and regulation that deny women's roles in the society.

This article focuses on the condition of African American woman Janie, the central black female character, as well as other characters such as Nanny and Joe who try to make their voices be heard in the society which is dominated by white male and black male standards and values. It also pays attention on the sense of selfhood, identity and self-realization of black women. Janie's search for her own identity forces one to see how she struggled to overpower the ways white people considered her blackness and oppressed her. Being exposed to her own blackness, Janie became conscious of the way blackness was observed. The inner force of her character and through her grandmother's life experience,she develops a kind of love and passion towards her blackness. By the time she grows up as an adult, she becomes conscious of her internal transformation in her character through her new experiences in three successive marriages. Towards the end of her second marriages her identity takes a new form i.e. fixed kind of self-realization. In her last marriage to Tea Cake, her search for identity is accompanied by her self-protection and self-vitality which leads to her decision to kill Tea Cake rather than being killed by him. Thus, Janie proves herself to be a great female hero and a great character of Hurston's novel, Their Eyes Were Watching God.

\section{Works Cited}

Balibar, Etienne. "Subject and Subjectivation." Supposing the Subject. Joan Copjec. London: Verson, 1994. $1-15$

Bertens, Hans. Literary Theory: The Basics. London: Routledge, 2001.

Bloom, Harold. Zora Neale Hurston. New York: InfoBase Publishing, 2007.

Bressler, Charles. Literary Criticism: An Introduction to Theory and Practice. New York: Routledge, 1984. Descartes, Rene. Discourse on the Method and Meditation. New York: Dover Publications, 2003. 
Frantz, Fanon. Black Skin, White Masks. Trans. Charles Marlmann. London: Pluto P, 2008.

Gregory, Lady Augusta. Selected Writings. Ed. Lucy McDiarmid. London: Penguin, 1995.

Hurston Zora Neale. Their Eyes Were Watching God. New York: Harper Collins, 2009.

Rivkin, Julie and Michael Rayne (eds.). Literary Theory: An Anthology. Oxford: Blackwell, 2004.

Tyson, Lois. Critical Theory Today. New York: Routledge, 2006.

Washington, Helen Mary. "I Love The Way Janie Crawford Left Her Husband: Zora Neale Hurston's Emergent Female Hero." Zora NealeHurston's Their Eyes Were Watching God. Ed. Harold Bloom. New York: InfoBase Publishing, 2008. 9-22. 
